\title{
RESOURCE MOBILIZATION ANALYSIS OF LAWYERS' MOVEMENT IN PAKISTAN (2007-2009)
}

\section{Muddasser Jatala $^{1 *}$, Syed Akmal Hussain ${ }^{2}$, Akhlaq Ahmad ${ }^{3}$}

${ }^{1 *}$ Ph.D., Scholar, Department of History \& Pakistan Studies, Faculty of Social Sciences, Faculty Block \#I, First Floor, New Campus, Sector\#H-10, International Islamic University, Islamabad, Pakistan; ${ }^{2}$ Ph.D., Assistant Professor, Department of History \& Pakistan Studies, Faculty of Social Sciences, Faculty Block \#I, First Floor, New Campus, Sector\#H-10, International Islamic University, Islamabad, Pakistan; ${ }^{3} \mathrm{Ph} . \mathrm{D}$., Assistant Professor, Department of Sociology, Faculty of Social Sciences, Faculty Block \#I, Ground Floor, New Campus, Sector\#H-10, International Islamic University, Islamabad, Pakistan.

Email: ${ }^{1 *}$ muddasserjatala@ hotmail.com, ${ }^{2}$ akmal.hussain@iiu.edu.pk, ${ }^{3}$ akhlaq.ahmad@iiu.edu.pk Article History: Received on $10^{\text {th }}$ June 2021, Revised on $20^{\text {th }}$ June 2021, Published on $23^{\text {rd }}$ June 2021

\begin{abstract}
Purpose of the study: The purpose of the study is to define and analyse the lawyers' movement in Pakistan remains an active social movement from 2007 to 2009.

Methodology: Qualitative research approach is the utmost appropriate approach to explore the resources mobilization process, in the lawyers' movement in Pakistan. To achieve deeper insights into the actions, perceptions, and experiences of the respondents in the lawyers' movement of Pakistan, almost 20 open-ended interviews were taken in-depth and mostly face-to-face interviews. Give one more line of info about methodology.
\end{abstract}

Main Findings: The lawyers' movement emerged in March 2007 in reaction to the unconstitutional dismissal of Chief Justice (CJ) of Supreme Court Pakistan by former General Pervez Musharraf. The lawyers' movement was the ultimate result of judicial-executive contention in Pakistan.

Applications of the Study: This paper will offer analyses of the lawyers' movement in the context of a social movement from a non-western country like Pakistan. This paper seeks to examine the lawyers' movement (2007-2009) to explore the resource mobilization in the lawyers' movement in Pakistan.

Novelty/Originality of this study: The resource mobilization theory (RMT) has been utilized as the theoretical framework with the acumen of qualitative approach for this investigation in the non-western setting.

Keywords: Lawyers Movement, Resource Mobilization, Networks, Legitimacy, Rule of Law.

\section{INTRODUCTION}

The lawyers' movement emerged in March 2007 in reaction to the unconstitutional dismissal of Chief Justice (CJ) of Supreme Court Pakistan Iftekhar Muhammad Choudhry by former General Pervez Musharraf. The lawyers' movement was an ultimate result of judicial-executive contention in Pakistan when Supreme Court asserted its independence unlike its historical role (Khan and Kasi, 2016). However, favours' given to military executives from time to time at the cost of judicial independence made the former strong enough to feel unbridled (Levinson, 2016). In the past, Justice Munir had justified and legalized the undemocratic and unconstitutional step of Governor-General Ghulam Muhammad on the ground of necessity (Jalal, 1995). Consequently, the military coup of 1958, 1969, 1977, and 12 October 1999, has been directly involved in politics and legitimized on the same ground of necessity ( the lawyers' fraternity continued their struggle and played a significant role in postcolonial Pakistan's social and political life (Siddiqa, 2019). Pakistan had experienced four martial laws (1958, 1969, 1977, and 1999) from independence to up till now. The bar associations became organized and emerged as a lawyers' fraternity platform for resistance and mobilization against the military coups (Majeed and Hashmi, 2020). The lawyers' fraternity became very active in the MRD, by challenging and resisting General Zia-ul-Haq by participating in the public protests when all political activities were banned and suppressed by the military regime (Hussain, 2007).

In 2007, when the regime attacked the judiciary by sacking its Chief Justice, the lawyer's fraternity became united to defend the judiciary's independence. Iftekhar Muhammad Choudhry was elevated as Chief Justice of Supreme Court of Pakistan in 2005 and occupied the office in 2000 under provisional Constitutional (PCO) of General Pervez Musharraf (Blue et al 2008). Choudhry started to institutionalize the various broad changes at the judiciary after being appointed CJ. From 2005 to 2007, Choudhry became popular due to using the power of suo motu actions to check misuse of power and mal governance in-country (Khan, 2014). In the year 2006, CJ opened the door for public interest litigation under the jurisdictions of suo moto powers. Particularly, the CJ decision on the privation of Pakistan Steel Mills, the police excesses and detain cases and other issues of misuse of powers of government officials were highly appreciated by the general masses. Despite these cases, the most sensitive and contentious cases were the missing person case and the right to hold the dual public office especially relating to General Musharraf (Khan, 2014). General Musharraf, considered the chief justice a thorn in his side due to these factors and reasons. On March 9, 2007, the Chief Justice of Pakistan was asked to resign from the office. The refutation of CJ enraged General Musharraf and he was detained at the Army House for approximately five hours. In those five hours, General Musharraf appointed Justice Javed Iqbal as a new Chief 
Justice of the Supreme Court of Pakistan, without following the procedure (Khan and Newberg, 2010). After that, he immediately called a meeting of the Supreme Judicial Council and put a reference against CJ Choudhry with many allegations of misuse of powers. Pakistan had been witnessed for the lawyer's movement (Nandy, 2020).

But it was the surprising moment in the history of Pakistan; a chief justice stared at a general's eye and did not blink. The principled stand of CJ Choudhry generated the grand narrative "independence of Judiciary" which attracted popular support. However, it was at this point in Pakistan's postcolonial history, the lawyer's fraternity got an opportunity not only to initiate and even lead the movement as a vanguard, which is referred to as a lawyers' movement (Rasheed and Mukhtar, 2020). Therefore, it was a peak point of movement, when General Musharraf suspends the constitution of Pakistan and imposed an emergency on 3 November 2007. Consequently, people from all walks of life included citizen groups, umbrella networks, students, organizations, and political parties amply supported and participated in the lawyer's movement and jointly produced a compelling rhetorical narrative for the lawyers' movement that had popular appeal. In these circumstances, general elections were held in the country in February 2008. Lawyers lead the movement and it has been marked by civil society as a political era (Akhtar, 2020). The media as well as lawyer's voices are much essential for the country (McCartney and Zaidi, 2019). The lawyer's movement was the most critical point as it was the first protest movement against Army COAS (Shah, 2019).

The leadership of the lawyers' movement and some political parties and other stakeholders boycotted the elections. The main political parties PML-N and PPP contested the elections and got the majority and formed a coalition government in federal. Massive pressure and mobilization from the lawyers' movement with their alliances and public compelled General Pervez Musharraf to resign as an army chief later on the president of Pakistan. After that, PPP's government was also reluctant to accommodate the lawyers' movement's demand of restoring all deposed judges (Mullally, 2009). Finally, a long march was launched by the lawyers' fraternity in March 2009. Prime Minister Gilani announced the restoration of CJ Choudhry with other deposed judges on 16 March 2009 as the result of the final long march of the lawyers' movement (Shafqat, 2018).

In this wake, this research will offer the Pakistani lawyers' movement as a test case in the context of social movement. Thus, the current research seeks to examine the lawyer's movement (2007-2009) to explore the mobilization of resources in the lawyers' movement. Moreover, the proposed study will also examine the nonmaterial resources alongside investigating the material and human resources from the nonwestern context specifically Pakistan.

\section{Scholarship on Pakistan's Lawyer' Movement}

Abbas and Jasam (2009) articulated that the lawyer's movement provides an opportunity for the judiciary in Pakistan to grow as an independent that upholds the rule of law and supremacy of the constitution. Ghias (2010) describes how a politics of reciprocity explain the mobilization of lawyers' as the bench protected the bar from regime penetration, and the bar protected the bench from regime backlash. But this article does not contain any reference to the use of resources in the lawyers' movement. Ahmed (2010) in his remarkable work explored the nonviolent discipline of the lawyers' movement. Ahmed (2012) analyze the role of mass media in the lawyers' movement, particularly TV news channels and print media became pillars of support for the movement. This study explores that, mass media, particularly TV channels and social media play a vital role during movement. Faqir, et al (2013) analyze the struggle of the lawyers for judicial independence and describe the social roots of lawyers' movement for supporting the judiciary. Meanwhile, kalhan (2013) argues shift beginning due to Supreme Court activism which causes the emergence of broader lawyers mobilization generated a rich set of constitutional norms. Faqir (2014) analyze the judicial crisis during the Musharraf regime and discuss the lawyers' movement in the context of judicial activism in Pakistan. Khan and Kasi (2016) analyse most of judicial history with relation to Choudhry public interest litigation, and socio-political situation related to the emergence of the lawyer's movement. Shafqat (2017) examines the conditions under which judiciaries become politicized under authoritarian regimes focusing on the lawyers' movement 2007-2009 of Pakistan.

\section{THEORETICAL FRAMEWORK}

A traditional version of the resource mobilization theory has been utilized as the theoretical framework for this investigation in the non-western country like Pakistan. The resource mobilization approach focuses on the organization of individuals within a population that share preferences, to predict collective action and social movement activity (McCarthy \& Zald, 1977). The organizational forms spawned by social movements are referred to as social movement organizations (SMO), which associate with the goals and preferences of a social movement and attempt to implement them (McCarthy \& Zald, 1977). The aggregation of resources is the key mechanism by which a social movement works toward goal achievement (McCarthy \& Zald, 1977).

However, Cress and Snow (1996) classified the resources into four major categories i.e. moral (external support in form of legitimacy, solidarity, and sympathy), human resource (leadership, staff, cadre, participants, or people) material resource (wealth, finance, property, office building or space, meeting place, transport tangible goods, and employment, etc.) and informational resource (skills, information, knowledge, and technical expertise, etc.). Similarly, Edwards and McCarthy (2004) developed a category of resources into five major resources, which available to SMOs such as material, human, moral, cultural, and social-organizational resources. Further, movement legitimacy is an external 
resource and often originates outside of a social movement or SMO and is bestowed by an external source known to possess them. In this sense, legitimacy as a non-material moral resource has been included in the traditional RMT model to analyze the case of the lawyers' movement (Mahmood and Yasmeen, 2017).

To sum up, this research utilizes the resource mobilization theory by integrating material resources and intangible resources to explore the resource mobilization process of the lawyers' movement in developing countries like Pakistan.

\section{METHODOLOGY}

The qualitative research approach is the utmost appropriate approach to explore the resources mobilization process, in the lawyers' movement in Pakistan. In order to achieve deeper insights into the actions, perceptions, and experiences of the respondents in the lawyers' movement of Pakistan, an open-ended interview schedule was used for the in-depth and mostly face-to-face interviews. As such, respondents included lawyers, activists from civil society organizations, politicians and journalists, or media personals. Moreover, around 20 in-depth interviews were conducted from the knowledgeable active participant of the lawyers' movement. Possibly questionnaire could be given in annexure.

\section{RESULTS AND ANALYSIS}

\section{Theme A: Bar Associations as a Lawyers Movement Organization}

The interview data articulate that lawyers fraternity have a large in-built network of bar associations organizational structure across the country that was the primary resource in lawyers movement that could be easily mobilized other resources for collective action. The bar associations are autonomous entities but these are connected through the platform of the Pakistan Bar Council (PBC), which decides the rules of the game and criteria to resolve the issue at the local and national level. The lawyers described that each city and district has an office of the bar association. In the lawyer's movement, this decentralized bar association's organizational structure (but connected through the rank and file) became the primary organizational resource of the lawyers' movement. In the lawyer's movement, the organisational structure of bar associations worked as the organization of the lawyers' movement.

A senior lawyer shares his views

The lawyers' movement gave unique thinking not only to bar even to the whole nation. If the bar did not take a step to initiate the lawyers' movement, then more obviously the same military regime rules over the country even today. (Interview December 2019)

The bar associations as lawyers movement organization mobilized the lawyer's fraternity or members of bars as human resource, the physical infrastructure of bar association as a material resource and skilled leadership, for planning, making strategies and for generating more resources for activities. A lawyer stated that:

The infrastructure of bar associations throughout Pakistan is used as a basic resource of movement. It played a significant role to mobilize not only lawyers but the whole country due to its reach at the grassroots level. Our bar associations run through elected executive committee members. President is a leader of the bar and represents the bar members and the rest of the representatives are managerial staff or the bureaucracy of Bar association. The bar association throughout Pakistan follows the same criteria for membership, code of conduct, and election procedure.

In every bar association, the chambers or offices are allocated to the registered lawyers. Chambers are the office of a lawyer where a lawyer interacts with his client. Every bar association have a barroom, library, dispensary, cafes, lawyers chambers, and other facilities. Lawyers used the barroom to interact and discuss the different matters of common interest. Sometimes they use bar rooms for their official meetings and seminars. This vast physical infrastructure and facilities give an impression of an organization is well resourced and skilled in the context of resource mobilization. According to interview data, the lawyers' fraternity has debated, discussed; interact with their leaders, chalking out strategies, meetings, and seminars by using the same infrastructure of bar associations.

\section{The leadership of Lawyers' Movement}

According to interview data, the movement was led by the collective leadership of law practitioners, which was divided into two categories, Judges and lawyers. Judges were deposed later composed of one group led by Justice Choudhry. This group of leaders was considered symbolic leaders because their presence in the movement inspired and motivated the masses. Justice Iftekhar Muhammad Choudhry was the most important personality of this group and the figurehead of the lawyers' movement.

Leadership is not the hand of one individual but there were two groups of leaders, judges, and senior lawyers. The groups of judges were symbolic and motivational leaders. But the question of central leadership indeed emerged from Supreme Court Bar Association (SCBA) because we follow the hierarchy of the institution. A group of lawyers from SCBA including the current president and some former presidents lead the movement due to their high stature in lawyers' fraternity, media, and society. 
The second group of leaders belongs to the lawyers' fraternity. Barrister Aitzaz Ahsan, Munir A Malik, Tariq Mahmood, Ali Ahmad Kurd, and Hamid Khan emerged as the main leaders of the lawyer's movement. This group of leaders was engaged to conduct all the activities and mobilizes all necessary resources for the success of the lawyers' movement. They were all professional practising Supreme Court lawyers with a high calibre of intellect and skills. Munir A Malik was an important leader of the lawyers' movement and elected president of the Supreme Court Bar Association (SCBA) at the time of the eruption of the lawyers' movement. He was arrested many times during the movement and during detention remained seriously ill-being the model of state repression. Aitzaz Ahasan, lawyer turn politician come with his eloquent and logical speeches to mass rallies, poems, and innovative ideas, which enhanced the revolutionary spirit in the lawyer's fraternity. A supreme court lawyer Ali Ahmad Kurd belonged from Baluchistan and became very popular due to his flaming speeches and statement among the general masses after the outbreak of the lawyer's movement. He was an architect of the persistent cycle of protests, agitation and became a symbol of protest in the country. Substantial support from a different section of Baluchistan especially the involvement of nationalists parties of Baluchistan was possible due to his active participation and leading role in the lawyers' movement.

We trust on competencies of our leadership in the movement. The leadership of the movement becomes a source of motivation especially for the young lawyer due to their professional, strategic, and planning skills to organize the movement.

The lawyers' leadership successfully framed the goals of the movement and chalk out the strategies. Moreover, they integrated the network of bar associations across the country on the collective objective by motivating the lawyers' fraternity. The central leadership enhanced the communication among the bar leaders by using hierarchy, the organizational structure of bar association to achieve the objectives of the lawyer's movement.

\section{Decision-Making Mechanism in Lawyers Movement}

In the lawyers' movement, it was difficult to engage the entire lawyer fraternity and other civil society actors or networks in the decision-making body. The leadership of the lawyer's movement were already enjoyed high social and political stature formed the National Action Committee of Lawyers (NACL) to deal with the matters of the lawyers' movement. The prominent members of NACL were composed of the central leadership of the lawyers' movement including Munir A Malik, Aitaz Ahsan, Ali Ahmad Kurd Hamid Khan, and Tariq Mehmood, and some others. The NACL was the main decision-making body of the lawyer's movement. The mechanism of decision making as members of NACL consult with the members of bar PBC and SCBA and have a series of debates and discussions on important matters of movement when the majority of votes passed resolution then issues the order the presidents of all bar associations through SCBA across the country.

A national action committee for the lawyers' movement was formed at that time to deals with the issues of movement. Representatives of all bar associations participated in the meetings and conventions of NACL whenever they called the meeting.

The NACL decided to engage all Pakistan bar association's representatives in the decision-making process of the most important matters of the lawyers' movement. These all Pakistan bar representative conventions become the second tier of NACL. The NACL arranged many all Pakistan lawyers' representative conventions for consultation and deciding on the important matters of the lawyers' movement.

\section{Strategies and Tactics}

The movement uses a repertoire of strategies and methods to build pressure on the government to achieve its objectives. The boycott of the courts, sometimes full-day boycott, and sometimes boycott for hours were the main tactics of the movement. At the start of the lawyer's movement lawyers boycotted the courts for many days. Later on to continue the business of courts Thursday was fixed as weekly boycott day. The hunger strikes were another strategy which employed by the lawyer's movement. The largely crowded seminars and conventions of the lawyers across the country became an important feature of the lawyers' movement. When the movement leadership went to participate in such functions their journey to the destination took the form of the public procession which was used as useful strategies. The lawyers found to arrange the sit-ins and black days in the different cities across the country. The lawyers staged the Iffthikar day throughout Pakistan to commemorate the effort of deposed CJ. One black day was observed in November 2007 joined by all political and civil society forces. Some bar associations launched a signature campaign from the general masses and lawyers fraternity to show solidarity with the movement and protest against the regime. The long marches were launched by the lawyers' movement to pressurize the government. One long march started on 10 June 2008 from Karachi and on June 13 it reached in front of parliament in Islamabad. The final long march was launched by the lawyers' movement in March 2009 that brings the success of the movement.

\section{Theme B: Networks Resource.}

Commonly, social movement organization formed a network with various social networks as a communication platform for mobilization. The lawyers' movement created various alliances and networks (coalitional networks) with other groups. 


\section{Networking with the Intelligentsia}

The coalitional network with intelligentsia circles provided the theoretical backbone and develops the discourse of social movement as well as uplift the movement legitimacy by showing that movement is not limited to one specific group, but is a nationwide issue. The lawyers' movement caught the attention in the literary and academic circles and various scholars and professionals of different fields (even from faculty of medical and engineering colleges) regularly participated in the activities. These networks of scholars from different fields provided a solid theoretical backbone for the discourse of the lawyers' movement. The professors, writers, poets, and media journalists participated in the movement in different cities. These scholars and professionals from different fields were very resourceful and skilled participants and well versed in terms of rule of law and supremacy of the constitution.

\section{One senior lawyer describes his views}

It is unethical to refuse the fact, in the case of the lawyers' movement, academic knowledge or theoretical support from the scholars significantly escalated the movement nationwide. Even though, they were small in numbers but qualitatively high in stature for movement.

Even activist faculty members from the well renowned private university of Lahore not only actively participated in the lawyers' movement demonstration even though arrested by the police and detained into jail for some days. The columnists, journalists, and writers were become the victims of the General Musharraf repression due to their participation and support for the movement's cause. They were regularly throwing their pieces of writings in different newspapers and magazines.

\section{Students networks Participation}

Students became active in the nationwide lawyer's movement after the imposition of an emergency in 2007. One interesting thing found that students in this time were not organized through the campus unions and student organizations. Instead, small networks or groups of students from the private colleges and universities joined the movement and other public sector universities students joined later the movement. These students were belonging from the mostly middle and upper-middle class and more resourceful as compared to their previous generation students.

Said, one longtime civil society activist:

It was amazing to see the energy level, enthusiasm, and idealism of this generation of students. They were different from the previous generation. They were not chanting the slogans like haye and Gunda gardi nai chaly gy. I saw placard of one student "children of moderate enlighten reject you Dictator" and "we are citizens not your serf" some other slogans were "We will decide our own future"," Justice now", and "Stop playing with the law"

The data shows that despite their physical participation, they become the vanguard of another front that was social media sites and YouTube, etc. This young generation of students was equipped with excellent information technology (IT) skills and exposure to the internet world.

One civil society activist said:

We often credit mass media to support the movement, and we overlook the role of alternate media in the lawyers' movement. If you think my generation people like activists and lawyers were vanguards of lawyers' movement on alternate media who even face difficulty to run their smartphones. It was new generation students who started activism on alternate media at that time.

Students as a potential human resources of the lawyer's movement further mobilize the technological resource such as the internet world as a public sphere, which was not accessible for the majority of lawyers and other general masses. This alternate activism of students on the daily basis caught the attention of the world community. Further, students were fluent to utilize the language skills and social and political vocabulary to develop the discourse of movement on the internet.

\section{Networking of Civil Society Groups and NGOs}

NGOs and civil society groups like the other section of civil society joined the lawyers' movement. These civil society groups and NGOs provided popular support and mobilize resources in the lawyers' movement.

The response of the NGOs people to the movement, that support was fantastic. Overall these new emerging groups were knowledgeable about the social issues and good campaigners.

The NGOs were mostly active in the major cities and become the vehicle to connect the people with the lawyers' movement. They convinced their members and communities to join and support the lawyers' movement. The majority of these NGOs shared their previous experiences and ideas to promote the lawyer's movement.

One NGO member explained that 
Our development sector grows in the time of Musharraf but wrong is always wrong. we were engaged in the advocacy of the lawyer's movement on every forum. At that time major NGOs were conducting seminars and advocacy campaigns for movement and try to catch the attention of international groups to pressurize the Musharraf regime.

Some local civil society groups such as trader networks, or business communities provided the facilities in the small cities. Because NGOs were more active in the major cities and the local civil society groups provided the facility support to the movement during the cycle of protests across the country. These groups not only participated even offered sometimes water, juices, and sometimes food. This network was the real force in local markets and able to mobilize the people as human resource and mobilizes more resources in terms of facilities support.

Various NGOs and civic groups not only provided the human resource even further mobilized the more resource. Especially NGOs become the voice of the lawyers' movement in front of international media and community and provided their professional skills in advocacy and informational resource to the movement. Similarly, other civic networks such as trader unions and business communities provided a range of facility resources to the movement in the different cities of Pakistan.

\section{Political Parties Involvement}

The interview data shows that all opposition political parties played a decisive role in the lawyers' movement. The majority of the opposition political parties PPP, PML-N, JI, PTI, Khaksaar Tehreek, Awami National Party, and many other leftists and nationalist-leaning parties joined the movement with their members. The data show that despite the difference of opinion of political parties regarding discourse and objective of the movement, all parties mobilize their voters, supporters, members, and political party workers as a human resource in the lawyers' movement. The nature of cooperation in terms of resource mobilization varies from party to party. Some regionalist or leftist-leaning parties were very active in the movement. The nationalist or regional parties cannot mobilize the people on the large scale. From the religious parties, only JI have a countrywide and well organized structured of supporters and material resource. They mobilized their supporters and student wings throughout Pakistan in the movement. Further, the charismatic personality of Imran Khan attracted the youth and students in movement as a human resource. Initially, PML-N and PPP mobilized their supporter and party workers in the movement. Both parties end bargaining with Musharraf and decided to rid of the dictator through the movement. But after forming the government PPP, party leaders, workers, and supporters were gradually decreased from the activities of the movement. In contrast, PML-N has continuously supported the lawyer's movement by mobilizing their party leaders, supporters, and workers.

A senior lawyer explained

No doubt, political parties joined us and mobilized their networks on the grass-root level. We were comfortable due to their participation. But a better choice was not exiting for their survival else joining our hands.

All political parties joined the bandwagon of the lawyer's movement and provided logistic and facility support on different occasions with their capacity. The alliance between political parties and lawyers movement not only strengthen the movement even increased its ability to face the repression of the government.

However, developing networks with other ideological diverse networks was a difficult task in the lawyers' movement. The data from lawyers explained that broad goals adopted by the movement and the coalitions or alliances that were formed were very loose/weak as well as Musharraf was the common denominator for all. First, the slogan of "Rule of Law" and "Independence of Judiciary" was wide and vague enough for people to read it in many different ways. Finally, given all that, General Musharraf acted as a "common denominator" that seemingly held the movement together.

\section{Theme C: Monetary resources in lawyers' movement}

It is widely acknowledged that material and monetary resources are greatly needed in social movements. The data articulate that most of the monetary resources of the lawyer's movement generated by the bar associations by using its internal funds. They describe that every bar association have funds collected from registered members (lawyers) of bars annually.

\section{A senior lawyer explained}

We have our own internal mechanism for funds collection. Every bar association have their own funds collected from members on the monthly or annually. During the lawyers' movement, the major responsibilities took by the main bars and provided the huge funding but local bars also contributed. At that time lawyers participated a lot even though economic constraints were existing due to the boycott of courts.

The data explained that bar associations were responsible to conduct and organizes the different demonstrations and activities of the movement and every bar was responsible to sustain their own expenditure at the local level. On the postemergency phase after 3rd November, the scope of the lawyers' movement had been widened due to the jump of various civic networks or groups into the lawyers' movement. At this phase of the lawyers' movement, the need for monetary resources was drastically increased. They requested different actors such as the business community (Tajar, traders, 
shopkeepers) for monetary resources but the main political parties like PMLN, JI, and PTI to coordinate with movement to provide the different facilities. In the later stages, when the movement decided about the first and second long marches, that time they requested to the business community (Tajar, traders, shopkeepers) for the contribution of money due to resource constrain in the bar funds.

\section{Expenditure on space, Infrastructure, and protest facilities}

The lawyers' movement organization did not spend money to rent a buildings or offices, private space for meetings, seminars, and other official work of the lawyers' movement. Because the pre-existing network of bar associations become the backbone of the lawyer's movement and they utilized the bars material resources such as infrastructure, communication devices, other facilities for meetings, seminars, and other official work of the lawyer's movement. Consequently, the expenditure on space or infrastructure have been found zero in the lawyer's movement. Moreover, lawyers movement organization spend a huge proportion of money on the preparation of protest props such as banners, placards, black flags, black strips, loudspeakers, sound system, stage facilities, arrangement of logistics, or transport and sometimes accommodation. Finally, the movement organizers did not spend money on the publicity materials and media campaigns. These facilities are provided by the other coalitional network (mass media) free of cost.

\section{Theme D: Building Movement Legitimacy}

The legitimacy of social movement is a non material resource, which movement actors use through the power of words, symbols, slogans, and images to gain public sympathy and wider support (Gamson, 1995). The traditional RMT approach describes that the social movement's legitimacy primarily relies on media coverage, specifically how

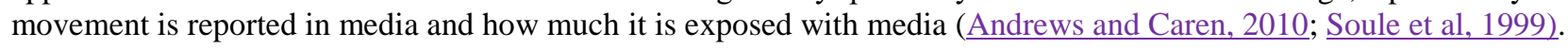

\section{Framing the Lawyers Movement Appeals}

The lawyers' movement organization used the diagnostic frame to identify the problem of the unconstitutional sacking of $\mathrm{CJ}$ and attack on the institution of the judiciary from the institution of the military.

They blamed military regime influence over the civilian institution specifically judiciary than parliament producing a lot of problems such as paralyzing civil institutions, amendments in the constitution, deterioration of the rule of law, and insecurity in the country.

The motivational frame of the lawyer's movement justifies the series of protests, relies on, and other actions conducted by the activists. The main motivational frame was justice for the general masses, which become the banner of the movement and moral obligation for the civil society to struggle against the unlawful act and paved the road for justice. The prognostic frame is referred to cope with the problem by proposing the solution. In the lawyers' movement, the major demand was placed from lawyers' organization, in fact, the objective and official slogan (Rule of Law) of the lawyer's movement was also a prognostic frame.

\section{Participation of Prominent Figures or Celebrities}

The participation of celebrities or prominent figures has found an efficient strategy to build the legitimacy of the lawyers' movement to gain public sympathy. The prominent figures or celebrities were invited in the processions, rallies, and other activities of movement to show the nonviolent nature of the movement, further to attract the masses.

It was the deliberate decision of our leadership to highlight the prominent figures from different fields. We invited on stage for giving some words or statement or sometimes speech for highlighting the issue in front of people and media.

Ms. Tahira Abdullah, I.A. Rehman, and Asma Janhgir are prominent human rights left-wing activists in Pakistan, enthusiastically participated in the important protests or events of the lawyer's movement. Their speeches, and struggles were broadcast by mass media, and police were arrested both during the mobilization. Ahmad Faraz a famous poet of Pakistan has regularly attended the important activities of the movement and some time as a special guest in processions recited his poetry in front of the masses. The involvement of Imran Khan as a former cricketer, philanthropist, and politician was proved a great asset for the attraction of youth. He utilized the movement to approach the young generation activists and students from the middle class to support the movement.

\section{The images of innocent students}

Another factor has been found to gain public support in the lawyer's movement. The media highlighted or spread the images and actions of students in the lawyers' movement. The new generation of student protests surprised the most people when media broadcast and transmitted their images with the title "heroes of movement".

Another lawyer explained his views regarding student participation

They did a lot of struggle with us and received baton-charged and tear gas during the protests. It was very painful for us our future generation is facing repression from the government. Their innocent images on media flame the whole society and gain public sympathy as well as these images justify the nonviolent nature of the lawyers' movement. 
The eye-catching images of these students are reported by mass media while chanting different slogans and dress up with fancy shirts and jeans. Where these powerful images affect the psyche of the public, on the other hand, national and international Media romanticized them as a new generation pursuing the road to democracy. However, the images, and scenes of movement which the electronic media broadcast to the entire nation, helped to build the lawyer's movement legitimacy.

\section{Role of Media to disseminate the lawyers' movement message}

The TV channels or electronic media in the lawyers' movement were more vibrant than print media. It was due to strong coordination and networking of media professionals with media advisors of the lawyer's movement in every bar association throughout the Pakistan.

The movement leadership employed the strategies for the media exposure; endorsing prominent figures of the movement, propagating the movement message to gain the wider public support for build the legitimacy of the movement.

The mass media provided the full coverage of lawyers' movement activities, protests such as Thursday strikes, black days, hunger strikes camps boycott of courts, long marches. For example, when the leadership of the movement decided to start the series of $\mathrm{CJ}$, visit with his companion lawyers in the bar associations across the country during the period from May to July 2007. All of these visits of CJ Choudhry were welcomed by the local bar associations, which get more attention from civil society and the general public. All of these events and welcome of CJ Choudhry with rose petals in different cities are broadcast by all TV channels and publish the stories of every newspaper. Another most important strategic aspect was deposed CJ Choudhry discussion and debate on the importance of rule of law and constitutional issues become the focal debate of every TV channel and newspapers in Pakistan, which further paved the way to gain the support from society. The full live coverage of all these events through electronic media and addresses and press releases of the leadership of the lawyers' movement become the discussion of news anchors in prime hours.

\section{DISCUSSION}

The RMT argues that social movements achieve success by effectively mobilizing their resources to fulfill the common objective (McCarthy \& Zald, 1977; Edwards and McCarthy, 2004; Della Porta \& Diani, 2006).

The lawyer's movement have been explained through RMT by its amount of resources such as organization, social networks, capital, and money media, and legitimacy, their application, and their management; using RMT, it can be seen that the lawyers' movement has been able to mobilize a variety of resources from very different channels through leadership, expertise, social networks, communication, and even logistical support from various groups and networks.

Consistent with the resource mobilization approach, the leaders of the lawyers' movement played a major role in the rise and success of the movement in Pakistan by utilizing a successfully preexisting organizational structure based on allocating essential resources to maximize impact and efficaciousness, which immensely influenced the movement's tactics and strategic decision-making process, attracted great numbers of conscience constituents to join and determined the movement's longevity and durability in a hostile political environment.

From the initiation phase, the movement's leader and cadre advanced the message of rule of law is the solution to frame issues meticulously to highlight the ills of society and to argue that there was a problem that needed to be addressed. By using the constitutional or legal frame, the movement tapped into the moral resource and enjoyed great legitimacy and supports among the elite civil society groups and educated middle class or through a message of rule of law.

This message of rule of law and supremacy of constitution not only gained the movement the legitimacy and moral resources needed to rise, growth and success, it also facilitated the material, and human resources highly needed for the different phases of lawyers' movement. Furthermore, even though the role of social networks and networking with other groups, which the lawyers movement utilized fully to operate, has been elucidating in the body of resource mobilization theory at the level of recruitment, the ideology and dynamics by which those networks influenced the movement in the different phases to follow was lacking and needed more exploration.

The lawyer movements accepted the political parties and other umbrella networks or groups' involvement or partisanship but as a participant or conscience constituents and it is maintaining equal distance from parties in decision making.

Resource mobilization theory narrates that monetary resource is one of the most important factors in all phases of social movement (Edwards \& McCarthy, 2004; Somma, 2010).

The findings of this research suggest that the lawyers' movement has successfully mobilized material and financial resources for achieving its objectives. Additionally, all their activities, the cycle of protests, and ventures were supported with material, technical, and financial resources in order to ensure success. Most of the time bar associations as a lawyers' movement organization uses their internal funds to fulfill the expenditure of lawyers' movement.

The lawyers' movement organization was largely dependent on their own bar members 'time, commitment, and monetary support. The RMT states that all members of a movement act rationally, and work towards or for their benefit, and look to their profits as motivation (Soule and King, 2008). 
However, this research discovered something to the contrary. The lawyers' movement organization or other participants of the lawyers' movement were utilized financial or material resources not to seek any personal, financial, or material benefits, other than moral obligation and satisfaction. They push themselves to be selfless and seem to work for principle stand on rule of law as a public good rather than for themselves.

They provided donations but they were not motivated by profit or any material gain. Many people from the movement that have abandoned great opportunities, financial and professional, they resigned from their jobs as a judges or government officials and lawyers fraternity sacrifices their economic interests by boycotting courts and, ignored their own needs, wages, comforts, and desires, even provided huge money from their packets and participated persistently in the movement for ensuring rule of law, and independence of the judiciary in the country. The commitment of the lawyers' fraternity is another thing worthy of mention that makes the lawyer's movement special.

The traditional RMT regarded movement legitimacy as an essential resource, which refers to support, and solidarity from outside the collective action (Walker and McCarthy, 2010; McLaughlin and Khawaja, 2000). In the case of the lawyer's movement, lawyers movement organization employed different strategies to build the lawyer's movement legitimacy such as networking with various networks, organization, or groups outside the movement, frame the movement message, and clearly define the boundaries between movement supporter and the opposite side as well as presenting movement icons, images and present the movement protests, or other activities, and scenes or placards, banners to show some symbolic meanings and slogans to attract the wider public support.

The whole legitimacy-building process as a non-material resource of lawyers' movement was possible through the coordination or interplay between lawyers' movement organization and mainstream mass media. Media to appeal to the people and gain large public support disseminated the movement's message.

In the lawyers' movement, the movement frames intend to attract a large number of supporters and specifically turned the adherent into the conscience constituents. Further, it increases the morale, spirit, and commitment of current supporters of the lawyers' movement. However, the network of black coats and black cameras work out to be a great combination that ultimately leads to success (Amin and Rehmat, 2016).

Media as a mode of communication covered the course and every moment of lawyers' movement, therefore, massage of movement easily reached out to the public through the TV channels (Ahmed, 2012). Another strategy was utilized was that the TV talk shows were arranged at the building of bar associations, footpaths, and press clubs. These were the institutions, which arbitrated critical thinking of the public sphere, the same way the saloons, coffee houses, and theatre were institutions of the public sphere in Habermas' description (Baxter, 1987).

The success and failure of a social movement largely depend upon content and symbolic projections by the media. Because it was the media, support which make them easy for the legal fraternity and lawyers' movement organization to present the professional issue of the legal community into the wider public sphere. Finally, the supportive role played by mass media to contributes to the legitimacy building of the lawyers' movement.

\section{CONCLUSION}

The lawyers' movement in Pakistan remains an active social movement from 2007 to 2009. The research confirms the adaptation of the resource mobilization framework is useful for understating the process of resource mobilization that gave rise and success of the lawyers' movement in a non-western country like Pakistan.

This research also confirms that adaptation of a resource mobilization theory based on the notion of the successful organizational structure and effective leaders or movement entrepreneurs as factors in social movement mobilization can explain the rise, formation, and success of the lawyers' movement in Pakistan.

Whilst the core dimensions of the resource mobilization framework served as a key factor to facilitate the growth, the utilization of these resources by the movement's leader and cadre played a major role in determining the success of the movement.

The role of the leadership of the lawyer's movement by utilizing preexisting lawyers organization as lawyers movement organization based on allocating essential resources to maximize impact and efficaciousness, which immensely influenced the movement's tactics and strategic decision-making processes, attracted great numbers of conscience constituents or participants to join and determined the movement's goals and durability in a hostile political environment.

The RMT of the lawyers' movement explains that the LM was a civil society movement and had similar characteristics and resource mobilization with other global social movements. It is affirmed that the application of RMT of social movement is not confined to the western setting as well as most appropriate for the analyses of non-western countries like Pakistan.

Finally, prospective social movements can be successful not only globally or in western countries even in non-western countries if they adopt the similar resources, leadership, goals, and values that the lawyers' movement mobilized. 


\section{AUTHOR'S CONTRIBUTION}

Muddasser Jatala: Acquisition of data, drafting the manuscript, statistical analysis.

Syed Akmal Hussain: Critical analysis with intellectual output.

Akhlaq Ahmad: Conception and design of the study, critical analysis with intellectual output. Writing the results \& interpretation.

\section{REFERENCES}

1. Abbas, A., \& Jasam, S. (2009). A ray of hope: The case of Lawyers' Movement in Pakistan. Pakistan. Reality, Denial and the Complexity of its State, 16, 140-170.

2. Ahmed, Z. S. (2012). The Role of the Pakistani Mass Media in the Lawyersâ€тM Resistance against the Musharraf Dictatorship, 2007-2009. Pakistaniaat: A Journal of Pakistan Studies, 4(3), 61-77.

3. Ahmed, Z. S., \& Stephan, M. J. (2010). Fighting for the rule of law: civil resistance and the lawyers' movement in Pakistan. Democratization, 17(3), 492-513. https://doi.org/10.1080/13510341003700360

4. Amenta, E., Caren, N., \& Stobaugh, J. E. (2012). Political reform and the historical trajectories of US social movements in the twentieth century. Social Forces, 90(4), 1073-1100. https://doi.org/10.1093/sf/sos067

5. Amin, H., \& Rehmat, S. (2016). Lawyers' movement and social movement theory: A critical Analysis. Pakistan Journal of Criminology, 8(1), 41.

6. Andrews, K.T. and N. Caren (2010). Making the news: movement organizations, media attention and the public agenda. American Sociological Review, 75(6), 841-66. https://doi.org/10.1177/0003122410386689

7. Baxter, H. (1987). System and Life-World in Habermas's Theory of Communicative Action. Theory and Society, 16, 39-86. https://doi.org/10.1007/BF00162659

8. Blue, R., Richard, H., \& Berg, L. A. (2008). Pakistan rule of law assessment final report.[Washington, DC]: United States Agency for International Development (USAID).

9. Cress, D. M., \& Snow, D. A. (1996). Mobilization at the margins: Resources, benefactors, and the viability of homeless social movement organizations. American sociological review, 61(6), 1089-1109. https://doi.org/1 $0.2307 / 2096310$

10. Della Porta, D./ Diani, M. (2006): Social Movements. An Introduction. Oxford: Blackwell Publishing.

11. Edwards, B., \& McCarthy, J. D. (2004). Resources and social movement mobilization. The Blackwell companion to social movements, 116-152. https://doi.org/10.1002/9780470999103.ch6

12. Faqir, K. (2014). Judicial Crisis in Pakistan during Musharraf Regime. Pakistan Journal of History and Culture, 35(2).

13. Faqir, K., Islam, F., \& Rizvi, S. H. (2013). The lawyers movement for judicial independence in Pakistan: A study of Musharraf regime. Asian Journal of Social Sciences \& Humanities, 2(2), 345-357.

14. Fuchs, C. (2006). The self-organization of social movements. Systemic practice and action research, 19(1), 101-137. https://doi.org/10.1007/s11213-005-9006-0

15. Gamson, W. (1995). Constructing social protest. In H. Johnston \& B. Klandermans (Eds.), Social movements and culture (pp. 85-106). London: UCL Press.

16. Ghias, S. A. (2010). Miscarriage of chief justice: judicial power and the legal complex in Pakistan under Musharraf. Law \& Social Inquiry, 35(4), 985-1022. https://doi.org/10.1111/j.1747-4469.2010.01211.x

17. Hussain, I. S. (2007). Pakistan: A Proud Nation, But Failing State. Lahore: Humanity International.

18. Jalal, A. (1995). Democracy and authoritarianism in South Asia: A comparative and historical perspective (No. 1). Cambridge University Press. https://doi.org/10.1017/CBO9780511559372

19. Kalhan, A. (2013). Gray Zone Constitutionalism and the Dilemma of Judicial Independence in Pakistan. Vand. J. Transnat'l L., 46, 1.

20. Khan, A. F., \& Newberg, P. R. (2010). The Pakistani Lawyers' Movement and the Popular Currency of Judicial Power. Pakistan Harvard Law Review, 123(1705), 17-18.

21. Khan, a. Q., \& kasi, a. Z.(2016). Executive-judiciary interaction and movement for independent judiciary in pakistan: 2007-09. International journal of political science, law and international relations, 6(1), 1-8.

22. Khan, M. S. (2014). Genesis and evolution of public interest litigation in the supreme court of Pakistan: toward a dynamic theory of judicialization. Temp. Int'l \& Comp. LJ, 28, 285.

23. McCarthy, J. D., \& Zald, M. N. (1977). Resource mobilization and social movements: A partial theory. American journal of sociology, 82(6), 1212-1241. https://doi.org/10.1086/226464

24. McLaughlin, P. \& Khawaja, M. (2000). The organizational dynamics of the U.S. environmental movement: Legitimation, resource mobilization, and political opportunity. Rural Sociology, 65(3), 422-439. https://doi.org/10.1111/j.1549-0831.2000.tb00037.x

25. Mullally, S. (2009). A Long March to Justice: A Report on Judicial Independence and Integrity in Pakistan. International Bar Association, Human Rights Institute.

26. Riaz, S. (2009). Coverage of the Issue of Judiciary Crisis in National Newspapers of Pakistan. Journal of Political Studies, 16, 81 . 
27. Shafqat, S. (2018). Civil society and the lawyers' movement of Pakistan. Law \& Social Inquiry, 43(3), 889-914. https://doi.org/10.1111/1si.12283

28. Somma, N. M. (2010). How do voluntary organizations foster protest? The role of organizational involvement on individual protest participation. The Sociological Quarterly, 51(3), 384-407. https://doi.org/10.1111/j.15338525.2010.01178.x

29. Soule, S. A., \& King, B. G. (2008). Competition and resource partitioning in three social movement industries. American Journal of Sociology, 113(6), 1568-1610. https://doi.org/10.1086/587152

30. Soule, Sarah A., Doug McAdam, John McCarthy, and Yang Su (1999) Protest Events: Cause or Consequence of State Action? The U.S. Women's Movement and Federal Congressional Activities, 1956-1979. Mobilization, 4, 239-55. https://doi.org/10.17813/maiq.4.2.v01017723m8p2w04

31. Tilly, C. (1978). From mobilization to revolution New York. McGraw-Hill.

32. Walker, E. T., \& McCarthy, J. D. (2010). Legitimacy, strategy, and resources in the survival of communitybased organizations. Social problems, 57(3), 315-340. https://doi.org/10.1525/sp.2010.57.3.315

33. Levinson, Daryl J.(2016). Looking for Power in Public Law. Harv. L. Rev., 130 (2016), 31.

34. Siddiqa, A.(2019). Pakistan-From Hybrid-Democracy to Hybrid-Martial Law. Journal of South Asian and Middle Eastern Studies, 42(2), 52-72. https://doi.org/10.1353/jsa.2019.0008

35. Majeed, G,. and Hashmi, R. S. (2020). Baloch Resistance during Zulfiqar Ali Bhutto's Era: Causes and Consequences. South Asian Studies, 29.

36. Nandy, D.(2020). Making Sense of Civil Society: The Experience of Pakistan, Afghanistan and Nepal. Building Sustainable Communities. Palgrave Macmillan, Singapore, 521-546. https://doi.org/10.1007/978-981-15-2393$\underline{9} 26$

37. Rasheed, A. and Mukhtar, H. (2020). Judicial Activism in Pakistan: A Case Study of the Tenure of Mr. Saqib Nisar Ex-Chief Justice. Journal of the Research Society of Pakistan, 57(1).

38. Khan, M.(2019). Empowerment without Accountability? The Lawyers' Movement in Pakistan and its Aftershocks. https://doi.org/10.19088/1968-2019.130

39. Akhtar, N.(2020). Rising Middle Class in Pakistan: A Changing Political Culture. Pakistan Journal of Social Sciences (PJSS), 40(3), 1281-1290.

40. McCartney, M, and S. Akbar Zaidi, eds.(2019). New Perspectives on Pakistan's Political Economy: State, Class and Social Change. Vol. 9. Cambridge University Press. https://doi.org/10.1017/9781108761154

41. Mahmood, Amna, and Samina Yasmeen (2017). Lawyers'movement and Executive-Judiciary Relations in Pakistan. South Asian Studies, 32(2).

42. Shah, A. (2019). 3 Institutions Matter. New Perspectives on Pakistan's Political Economy: State, Class and Social Change, 9(2019), 75. https://doi.org/10.1017/9781108761154.005 